\title{
Site-related and seasonal variation of bioaerosol emission in an indoor wastewater treatment station: level, characteristics of particle size, and microbial structure
}

\author{
Wenjie Ding $\cdot$ Lin Li $\cdot$ Yunping Han • \\ Jianzhong Liu $\cdot$ Junxin Liu
}

Received: 9 March 2015 / Accepted: 26 May 2015/Published online: 6 June 2015

(C) Springer Science+Business Media Dordrecht 2015

\begin{abstract}
The emission of the airborne bacteria and fungi from an indoor wastewater treatment station adopting an integrated oxidation ditch with a vertical circle was investigated. Microbial samples were collected by the six-stage viable Andersen cascade impactor, and the samples were collected in triplicate in each sampling site per season. Culture-based method was applied to determine the concentrations of the airborne bacteria and fungi, while the cloning/ sequencing method was used to characterize the genetic structure and community diversity of airborne
\end{abstract}

W. Ding · L. Li $(\bowtie) \cdot$ Y. Han · J. Liu

Department of Water Pollution Control Technology, Research Center for Eco-Environmental Sciences, Chinese Academy of Sciences, Beijing 100085, China e-mail: leel@rcees.ac.cn

W. Ding

e-mail: dingwenjie2005@126.com

Y. Han

e-mail: yphan@rcees.ac.cn

J. Liu

e-mail: jxliu@rcees.ac.cn

J. Liu

Department of Chemical Engineering, China University of Mining and Technology, Beijing 100083, China e-mail: Liujianzhongno1@163.com bacteria. The highest concentrations of airborne bacteria $\left(4155 \pm 550 \mathrm{CFU} / \mathrm{m}^{3}\right)$ and fungi $\left(883 \pm 150 \mathrm{CFU} / \mathrm{m}^{3}\right)$ were obtained in June (summer). The lowest concentration of bacteria $\left(1458 \pm 434 \mathrm{CFU} / \mathrm{m}^{3}\right)$ was determined in January (winter), and the lowest concentration of fungi $\left(169 \pm 40 \mathrm{CFU} / \mathrm{m}^{3}\right)$ was found in March (spring), respectively. The particle size distribution analysis showed that most culturable bacteria obtained in all the sampling sites were in the particle size range of 1.1-4.7 $\mu \mathrm{m}$. Most culturable fungi had particle sizes in the range 1.1-3.3 $\mu \mathrm{m}$. Microbial population analysis showed that Bacillus sp., Acinetobacter sp., and Lysinibacillus were the main groups obtained in S1. Enterobacter was the dominant group in sampling site S2. Both the concentrations and particle size distribution of the bioaerosols in the enclosed space presented a seasonal and site-related variation. Concentration and richness of microorganisms in bioaerosols in June were higher than in September and January. The particle size distribution varied between the sampling sites, and proportion of large particles was higher in S2 than in S1 because of the settlement of large particles. Pathogenic species, such as Acinetobacter lwoffii, Staphylococcus saprophyticus, and Enterobacter sp., were isolated from the bioaerosols, which could pose serious latent danger to sewage workers' health.

Keywords Bioaerosols · Clone library - Oxidation ditch $\cdot$ Enclosed space $\cdot$ Wastewater treatment station 


\section{Introduction}

The degradation of pollutants in the wastewater treatment plants (WWTPs) mainly results from the metabolism of numerous microorganisms. A great number of microorganisms, e.g., bacteria, fungi, virus, and protozoa, exist in the wastewater and wastewater treatment systems (Fracchia et al. 2006; Gangamma et al. 2011; Heinonen-Tanski et al. 2009). Numerous saprophytic and potentially pathogenic microorganisms are also present in raw wastewater (Filipkowska 2003; Kay et al. 2008; Korzeniewska et al. 2009). The transfer of microorganisms from water to the air results in the generation of bioaerosols, which pose a potential microbial epidemic threat and health hazard to the surrounding environment and to WWTP workers. The risk of infections associated with WWTP bioaerosols has been a cause for concern and has been studied in recent years. Studies indicated that allergic rhinitis, asthma, chronic bronchitis, allergic alveolitis, and organic dust are major groups of respiratory diseases that are associated with exposure to bioaerosols from WWTPs (Douwes et al. 2003).

The type and quantity of bioaerosols vary from plant to plant depending on the type of equipment used, treatment capacity, operating conditions, and environmental conditions (Gangamma et al. 2011; Huang et al. 2002; Li et al. 2011; Pillai and Ricke 2002). Bioaerosols emitted from different stages in an activated sludge wastewater treatment plant have been collected by an Anderson sampler (Malakootian et al. 2013). The maximum concentrations of bacterial aerosols have been found in the sludge aerobic digester unit $\left(1537 \mathrm{CFU} / \mathrm{m}^{3}\right)$. The emission levels of airborne bacteria and fungi from different aeration systems in two WWTPs were compared. Results showed that fixed-film reactor generated less microbial emission than the activated sludge plant (Bauer et al. 2002; Brandi et al. 2000).

The transfer of the microorganisms from wastewater to the air occurs during the progression of different phases or processes of aeration in WWTPs. Aeration and mechanical agitation of wastewater can produce air bubbles, and the eruption of such bubbles can form bioaerosol particles containing bacteria and viruses. The bioaerosol emission of different aeration systems was compared, and results showed that aeration systems based on horizontal rotors produced the highest amount of airborne bacteria, reaching up to
$3.9 \times 10^{4} \mathrm{CFU} / \mathrm{m}^{3}$ (Filipkowska et al. 2000). Six different WWTPs were monitored to evaluate the effect of the aeration system on airborne microorganism levels, and results showed that air diffuser aerators generated lower amount of bioaerosols than mechanical agitation of the wastewater (Sanchez-Monedero et al. 2008).

Moreover, meteorological conditions could determine the survival of the microorganisms in the air. Variations in temperature can change the bacterial concentration of aerosols, and an increase in the degree of moisture increases bacterial retention time (Handley and Webster 1995; Marthi et al. 1990). When relative humidity was higher than $35 \%$, the amount of airborne microorganisms increased (Haas et al. 2010).

The development of various analysis techniques based on DNA extracted directly from natural samples has helped detect unculturable airborne microorganisms and characterize their genetic structure and community diversity in complex environments (Fahlgren et al. 2011; Han et al. 2012). Polymerase chain reaction (PCR)-based methods have been used to detect and quantify aerosolized bacteria and fungi and to estimate the amount of airborne microorganisms in WWTPs. The cloning/sequencing method is an effective technique that can be used to examine microbial quality and analyze community composition and diversity (Maron et al. 2005; Polymenakou et al. 2008).

Most wastewater treatment facilities of the WWTPs are built outdoors because of the large occupation area. In villages or small towns, treatment plants are small. Moreover, treatment facilities are usually installed indoors, especially in cold areas.

Previous reports mainly focused on the bioaerosols emitted from WWTP outdoor facilities, but an evaluation of bioaerosols released from indoor WWTP facilities is still lacking. Up till now, there is little known about bioaerosol emitted from wastewater treatment facilities built indoor especially in China. Understanding the microbial characteristics of bioaerosols emitted from the enclosed WWTP will benefit for the development of effective control methods.

In the present study, microbial samples including airborne bacteria and fungi were collected during four seasons by six-stage viable Andersen cascade impactor to investigate the bioaerosol emitted from an indoor wastewater treatment station (WWTS) in 
Beijing. Conventional culture method and molecular biology technologies were applied to determine the concentration of bioaerosols and their microbial population origins. Seasonal variation of the microorganisms present and site-related distribution characteristics were also investigated. We aimed to provide suitable suggestions for the protection of WWTS workers and scientific data for controlling bioaerosol in indoor treatment facilities by characterizing the level, particle size distribution, and microbial populations of bioaerosols in the WWTS.

\section{Materials and methods}

\subsection{Sampling locations}

The present investigation was conducted in a WWTS that uses an integrated oxidation ditch process with vertical circle. The treatment capacity was $100 \mathrm{~m}^{3} /$ day. An oxidation ditch is located indoors to maintain suitable temperature in winter and to prevent solarization in summer. As aeration devices, rotating brushes operating at a speed of $50 \mathrm{rpm}$ were installed in the oxidation ditch. Chemical oxygen demand of the influent sewage was $400 \mathrm{mg} / \mathrm{L}$ on average, and over $90 \%$ of removal efficiency could be achieved after $10 \mathrm{~h}$ of hydraulic retention.

The two sampling sites ( $\mathrm{S} 1$ and $\mathrm{S} 2$ ) in the wastewater treatment station are shown in Fig. 1. The control measurement was performed in a clean

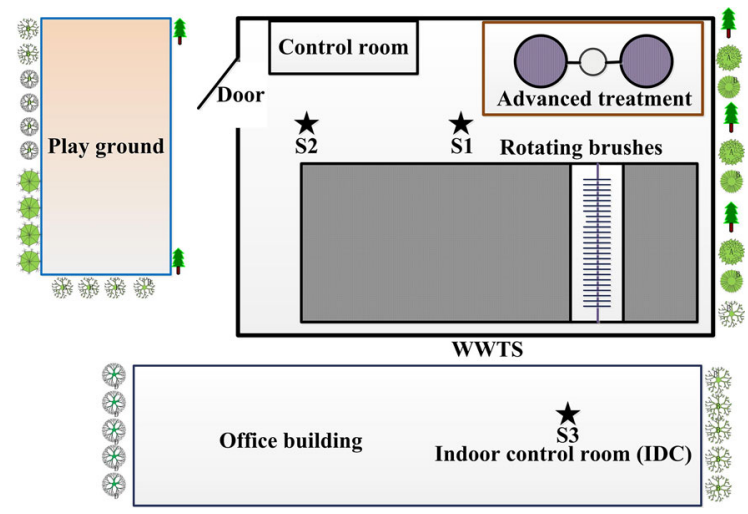

Fig. 1 Schematic diagram of sampling site locations. Star sampling sites; $S 12 \mathrm{~m}$ high above the ground and $1.5 \mathrm{~m}$ after the rotating brushes; $S 20.5 \mathrm{~m}$ high above the ground and $6.5 \mathrm{~m}$ after the rotating brushes; $S 31.5 \mathrm{~m}$ high above the ground in a clean room in the office building room (S3) located in an office building. Microbial samples were collected in triplicate at each sampling site. During sampling, the temperature and relative humidity $(\mathrm{RH})$ were recorded by a Dewpoint Thermohygrometer (WD-35612, OAKTON, Germany). Samples were collected between 10:00 a.m. and 12:00 a.m. in 1 day.

\subsection{Airborne microorganism capture}

A six-stage viable Andersen cascade impactor (228-9530 K, SKC Gulf Coast Inc. USA) was used to capture airborne microorganisms. This collector is a bioaerosol and microbial particle sizing sampler designed to measure the concentration and particle size distribution of aerobic bacteria and fungi in intramural or ambient air (Andersen 1958). Airborne microbial particles were separated into six fractions, and the aerodynamic cut-size diameters in the six stages were: $>7.0 \mu \mathrm{m}$ (stage 1), 4.7-7.0 $\mu \mathrm{m}$ (stage 2), 3.3-4.7 $\mu \mathrm{m}$ (stage 3), 2.1-3.3 $\mu \mathrm{m}$ (stage 4), 1.1-2.1 $\mu \mathrm{m}$ (stage 5), and 0.65-1.1 $\mu \mathrm{m}$ (stage 6). The glass Petri dishes containing suitable growth medium were kept under each stage of the sampler.

Air stream with a flow rate of $28.3 \mathrm{~L} \mathrm{~min}^{-1}$ was drawn through the sampler by a pump. Sampling time was typically $2 \mathrm{~min}$, and the corresponding impaction volume was $56.6 \mathrm{~L}$. Once the required volume of air had been drawn through, the glass Petri dishes were removed from the sampler, covered, inverted, and incubated. The process of bioaerosol capture has been described in our previous report ( $\mathrm{Li}$ et al. 2011). The sampler was sterilized in advance in an autoclave for 120 min. After collecting each sample, the sampler was sterilized with a $75 \%$ ethanol solution. Airborne bacteria from the collected air samples were cultivated in nutrient agar (BR, Aoboxing Biotech, Co. China) at $30{ }^{\circ} \mathrm{C}$ for $48 \mathrm{~h}$. Fungi were incubated in Rose Bengal Medium at (BR, Aoboxing Biotech Co., China) $30{ }^{\circ} \mathrm{C}$ for 7 days. Positive-hole correction method was used to determine colony count concentrations (Andersen 1958; Macher 1989). Results were calculated as the geometric mean of the replicates and expressed as colony-forming units per cubic meter of air $\left(\mathrm{CFU} / \mathrm{m}^{3}\right)$.

\subsection{DNA extraction and PCR amplification}

The cells grew up on each plate were collected for microbial analysis. And those from all the plates 
captured from the same sampling point were mixed before DNA extraction. DNA was extracted by an autoplate (TanBead, Taiwan) with Automatic Plateform for Magnetic System-16 (TanBead, Taiwan). The DNA bands were observed by $1.0 \%$ agarose gel electrophoresis. All samples were assayed in duplicate. The eubacterial 16S rDNA segments were amplified by PCR using the following universal primers: F16S-27 (5'-AGAGTTTGATCCTGGCTC AG-3') and R16S-1492 (5'-CGGTTACCTTGTTACG ACTTC-3'). PCR amplification was performed using the Gene AmpR PCR System (9700, AB, USA) at a final volume of $50 \mu \mathrm{L}$. The reaction mixture contained $2.0 \mu \mathrm{L}$ of both primers, $3.0 \mu \mathrm{L}$ of each dNTPs, $5 \mu \mathrm{L}$ of $10 \times$ PCR buffer (Takara, China), and $2.0 \mu \mathrm{L}$ of Taq DNA polymerase (TaKaRa, China). The temperature cycling conditions were $94{ }^{\circ} \mathrm{C}$ for $5 \mathrm{~min}$, followed by 25 cycles of $94{ }^{\circ} \mathrm{C}$ for $30 \mathrm{~s}, 56^{\circ} \mathrm{C}$ for $30 \mathrm{~s}$, and $72{ }^{\circ} \mathrm{C}$ for $90 \mathrm{~s}$. A final extension at $72{ }^{\circ} \mathrm{C}$ for $10 \mathrm{~min}$ was performed. After purification by an Agarose Gel Extraction Kit (Dingguo, China), the PCR products were ligated to the $1.0 \mu \mathrm{L}$ pMD19-T vector (Takara, China) and transformed into $E$. coli DH5 $\alpha$ competent cells. The clones were cultured on LB medium with $\mathrm{X}$-Gal, isopropyl $\beta$-D-1-thiogalactopyranoside, and Amp. A total of 50 clones were selected for PCR detection, and their positive clones were submitted for sequencing using the ABI 3730DXL DNA sequencer (AB, USA).

\subsection{Clone library construction and phylogenetic analysis of sequences in clone libraries}

Vector sequences were excluded by checking and trimming all the sequences obtained from the clone libraries. Then, the remaining sequences were checked for chimeras using Bellerophon on the Greengenes website (http://greengenes.lbl.gov/). DNAMAN software was used to align these sequences. The aligned sequences were grouped into universal operational taxonomic units (OTUs) at a threshold of $97 \%$ minimum similarity. Individual sequences were also grouped into OTUs to identify bacterial distribution in bioaerosols from different sampling months. The representative sequence of each OTU in the group-specific libraries was aligned to the NCBI database by the BLAST website. To identify the phylogenetic affiliation of all OTUs, a phylogenetic tree that included representative sequences of each OTU and related sequences from the previous NCBI database was constructed using the neighbor-joining algorithm by MEGA version 3.1.

\subsection{Diversity and richness estimation of clone libraries}

The coverage of each clone library was calculated according to Eq. (1), as follows:

$C=1-(n / N)$

where $n$ is the number of unique clones, and $N$ is the total number of sequences examined (Good 1953).

The Shannon Wiener index $(H)$ is widely used and has been used in the computation of bacterial species diversity. $H$ is calculated as follows:

$H=-\sum_{i=1}^{m} p i \ln p i$

where $p i$ is the proportion of individuals found in the $i$ th OTU of a sample of $\mathrm{m}$ different OTUs. The Shannon Wiener index has been described in previous reports (Ding et al. 2008; Li et al. 2011). The partial sequences of $16 \mathrm{~S}$ rRNA genes obtained in this study were submitted to the NCBI database under the accession numbers shown in Table 1.

\section{Results and discussion}

3.1 The emission of airborne bacteria and fungi in the WWTS

\subsubsection{The levels of airborne bacteria and fungi in WWTS}

Concentrations of airborne bacteria and fungi in each season in the WWTS are shown in Figs. 2 and 3. On average, the highest level of airborne bacteria was found in June $\left(4155 \pm 550 \mathrm{CFU} / \mathrm{m}^{3}\right)$, and the lowest level was found in January $\left(1458 \pm 434 \mathrm{CFU} / \mathrm{m}^{3}\right)$. The concentration of airborne bacteria in June exceeded the National Indoor Air Quality Standard of China $\left(2500 \mathrm{CFU} / \mathrm{m}^{3}\right)(\mathrm{GB} / \mathrm{T} 18883-2002$ 2002). The mean concentrations of airborne bacteria in $\mathrm{S} 3$ were only $153 \pm 26 \mathrm{CFU} / \mathrm{m}^{3}$ in January, $377 \pm 65 \mathrm{CFU} /$ $\mathrm{m}^{3}$ in March, $589 \pm 130 \mathrm{CFU} / \mathrm{m}^{3}$ in June, and $660 \pm 113 \mathrm{CFU} / \mathrm{m}^{3}$ in September. All water treatment facilities were set up in the house of the WWTS. 
Table 1 Accession numbers of OTUs from all samples in GenBank database

\begin{tabular}{lll}
\hline Sampling site & Names of OTU & Accession numbers \\
\hline S1 & JAN-1 to JAN-8 & KF453777-KF453784 \\
& JUN-1 to JUN-7 & KF228920-KF228926 \\
& JUN-9 to JUN-15 & KF228927-KF228933 \\
& SEP-1 to SEP-7 & KF228905-KF228911 \\
S2 & JUNL-1 to JUNL-13 & KF453764-KF453776 \\
\hline
\end{tabular}

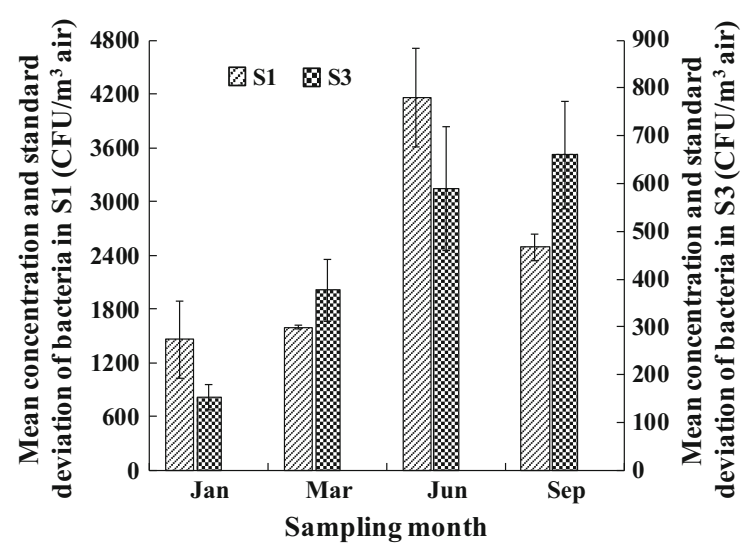

Fig. 2 Mean concentration and standard deviation of airborne bacteria in each month $\left(\mathrm{CFU} / \mathrm{m}^{3}\right.$ air $)$

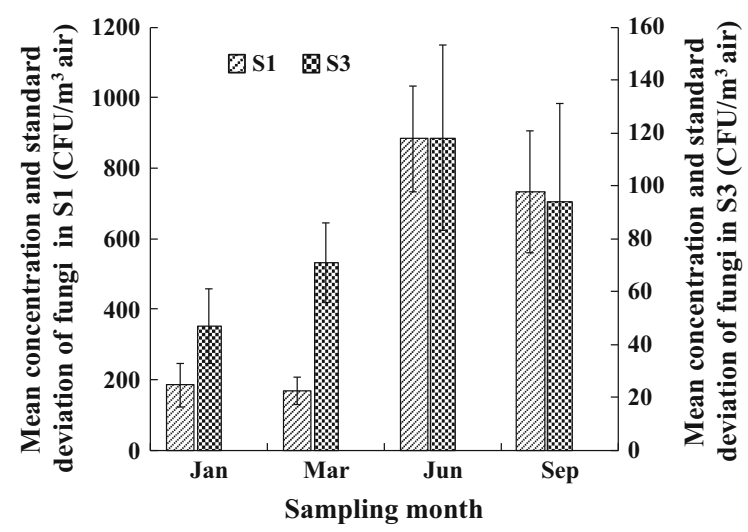

Fig. 3 Mean concentration and standard deviation of airborne fungi in each month $\left(\mathrm{CFU} / \mathrm{m}^{3}\right.$ air $)$

Ventilative equipment was installed in the WWTS to regularly supply fresh air. In the present study, the microbial samples were obtained prior to ventilation. The bioaerosols generated from the treatment facilities accumulated in the enclosed space. In addition, the roof of the WWTS protected the microorganisms from ultraviolet damage. Therefore, high concentrations of bacteria and fungi were present in the air phase of the WWTS.

The level of airborne fungi was much less than that of airborne bacteria. The highest airborne fungi level was observed in June $\left(883 \pm 150 \mathrm{CFU} / \mathrm{m}^{3}\right)$, whereas the lowest level was observed in March $(169 \pm 40 \mathrm{CFU} /$ $\mathrm{m}^{3}$ ). Levels of airborne fungi in IDC were $47 \pm 14 \mathrm{CFU} / \mathrm{m}^{3}$ in January, $71 \pm 15 \mathrm{CFU} / \mathrm{m}^{3}$ in March, $118 \pm 35 \mathrm{CFU} / \mathrm{m}^{3}$ in June, and $94 \pm$ $37 \mathrm{CFU} / \mathrm{m}^{3}$ in September. Penicillium, Aspergillus, and Candida were the fungal genera that occurred frequently in the air of the WWTS. Until recently, a standard for regulating the concentration of fungi in indoor air did not exist. Owing to their ability to produce mycotoxins, certain species of mold, such as Aspergillus and Penicillium, could contribute to air pollution and present a serious health hazard to WWTS workers when these mycotoxins accumulate in the air (De Luca et al. 2001; Li et al. 2011). Especially in highly humid environments, fungal spores can be released into the air, which could cause infections or allergic reactions in humans (Jones and Harrison 2004; Tsai and Liu 2009). Investigations on the toxicological mechanism of fungal aerosols are necessary.

The vertical oxidation ditch process was adopted in the WWTS for wastewater treatment. The vertical oxidation ditch has the following characteristics: compact configuration, economic space occupation, small investment and running expense, low energy consumption, and easy manipulation (Xia and Liu 2004). Rotating brushes were installed in the vertical oxidation ditch to aerate and drive water. The water in the oxidation ditch contained a large amount of microorganisms that would degrade the pollutants in water. The transfer of microorganisms from water to atmosphere occurs during the rotation of brushes, thereby resulting in the formation of the bioaerosols.

Airborne bacteria and fungi generated from an Orbal oxidation ditch in a wastewater treatment plant in Beijing were investigated, and $3952 \pm 730 \mathrm{CFU} /$ 
$\mathrm{m}^{3}$ of airborne bacteria were detected from the point near the rotating brushes in June ( $\mathrm{Li}$ et al. 2013). Approximately $8 \times 10^{4} \mathrm{~m}^{3} /$ day water was treated in the WWTP. An Orbal oxidation ditch was installed outside. The levels of both bacteria and fungi emitted from Orbal oxidation ditch were obviously lower than those that escaped from the vertical oxidation ditch in the WWTS because of the UV inactivation and air dilution. Only $2247 \mathrm{CFU} / \mathrm{m}^{3}$ of airborne bacteria was found in the indoor facilities of a WWTP with the conventional activated sludge (Brandi et al. 2000). Variations were probably due to the different treatment processes designed in the WWTP.

\subsubsection{Seasonal variation}

In Beijing, spring season is from March to May, summer season is from June to August, autumn is from September to November, and winter is from December to February. The levels of airborne bacteria and fungi in June and September were much higher than those collected in January and March, thereby indicating the seasonal variations in airborne bacteria and fungi emission. Relative humidity and temperature are the significant environmental parameters that affected the release and dispersal of bioaerosols, especially for those generated from the process units installed indoors (O'Gorman and Fuller 2008). Temperature and water availability would affect the release of some active bacterial and fungal spores. In environments with high humidity, fungal spores released into the air could cause infections or allergic reactions in humans (O'Gorman and Fuller 2008). High temperature and relative humidity favor microbiological growth. Peccia et al. (2001) found that bacterial cells absorb water from the atmosphere to maintain their activation and for protection against UV injury when the relative humidity is in the range 20-95\%. The temperature in summer was much higher than that in spring and

Table 2 Mean monthly temperature $(T)$ and relative humidity (RH) during a month in each season during the experiment

\begin{tabular}{llrl}
\hline Time & Season & \multicolumn{1}{c}{$T\left({ }^{\circ} \mathrm{C}\right)$} & RH $(\%)$ \\
\hline March & Spring & $11 \pm 1.15$ & $17 \pm 0.96$ \\
June & Summer & $27.4 \pm 0.58$ & $80 \pm 0.58$ \\
September & Autumn & $23 \pm 0.50$ & $53 \pm 0.60$ \\
January & Winter & $14 \pm 0.58$ & $20 \pm 0.58$ \\
\hline
\end{tabular}

winter (Table 2). The relative humidity levels during summer and autumn were 53 and $80 \%$, respectively. Thus, levels of bacteria and fungi that emerge in summer and autumn were higher than those of bacteria and fungi that emerge in spring and winter because of the suitable temperature and appropriate relative humidity during summer and autumn.

\subsubsection{Site-related emission of airborne bacteria and fungi}

Emission of airborne bacteria and fungi varied with distance from bioaerosol source. In the present study, the rotating brushes were considered to be the source of bioaerosols. In June, samples collected from S1 and S2 were analyzed to investigate the site-related emission of airborne bacteria and fungi. Compared with $\mathrm{S} 1$, the concentrations of airborne bacteria and fungi in S2 were reduced significantly. Sampling site $\mathrm{S} 1$ was located $1.5 \mathrm{~m}$ from the rotating brushes and $2 \mathrm{~m}$ above the ground, whereas sampling site S2 was located $6.5 \mathrm{~m}$ away from the rotating brushes and $0.5 \mathrm{~m}$ above the ground. The level of airborne bacteria present in $\mathrm{S} 2$ was $1313 \mathrm{CFU} / \mathrm{m}^{3}$, which was only $32 \%$ of the level in $\mathrm{S} 1\left(4155 \mathrm{CFU} / \mathrm{m}^{3}\right)$. The level of airborne fungi in $\mathrm{S} 2\left(203 \mathrm{CFU} / \mathrm{m}^{3}\right)$ was only $23 \%$ of the level in $\mathrm{S} 1\left(883 \mathrm{CFU} / \mathrm{m}^{3}\right)$ (Fig. 4). In general, most of the airborne bacteria and fungi adhered to the liquid droplet or to the dust particles in the air. The airborne bacteria and fungi settled along with the liquid droplet or the dust during sedimentation. In the WWTS, settlement occurred during the movement of particles from S1 near the rotating brushes to $\mathrm{S} 2$, thereby resulting in the decrease in amount of airborne bacteria and fungi in S2. The concentration of airborne

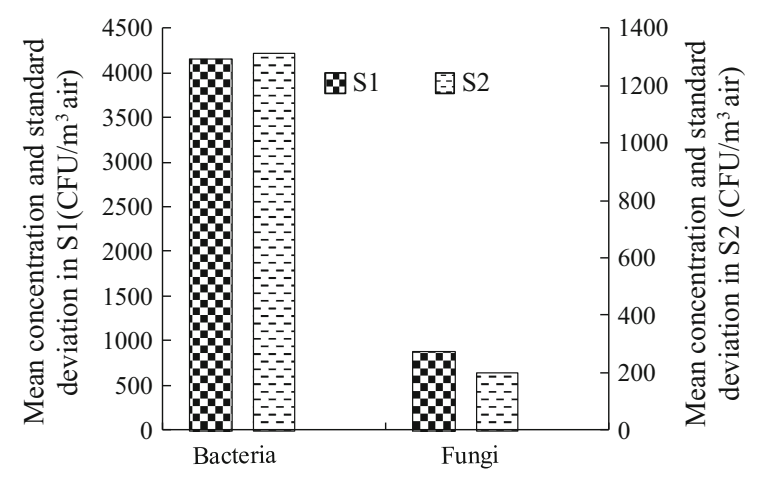

Fig. 4 Site-related emission of airborne bacteria and fungi in June 
bacteria was investigated in an Orbal oxidation ditch in a Beijing municipal WWTP, and outcome demonstrated that the airborne bacteria decreased dramatically with increasing distance from the rotating brushes ( $\mathrm{Li}$ et al. 2013). The concentrations of airborne bacteria and fungi that emerged in the air increased with increasing proximity to the bioaerosol source. Large amounts of airborne bacteria and fungi were detected from the sampling point near the rotating brushes in the present study.

\subsection{Particle size distributions of airborne bacteria and fungi}

\subsubsection{Seasonal variation of particle size distribution}

The Andersen sampler used to collect the samples can separate airborne particles by collecting them in stages with holes of different sizes. The particle size distributions of the total airborne bacteria and fungi from different sampling month are shown in Fig. 5. On average, the high concentrations of airborne bacteria in January and March were detected in stage 4, with hole sizes between 2.1 and $3.3 \mu \mathrm{m}$. The lowest value was detected in stage 1 , with hole sizes over $7 \mu \mathrm{m}$. In January, $62 \%$ of airborne bacteria were located in the size range of $2.1-4.7 \mu \mathrm{m}$. More than $64 \%$ of the airborne bacteria were found in the size range of 1.1-3.3 $\mu \mathrm{m}$ in March. However, the particle size distribution in June and September presented a different phenomenon; the highest level was observed in stage 3, with hole sizes in the range 3.3-4.7 $\mu \mathrm{m}$, and

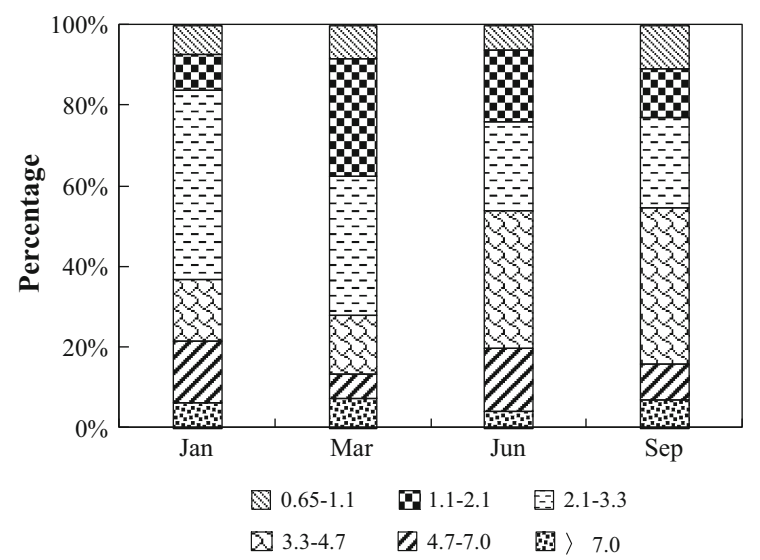

Fig. 5 Particle size distributions of airborne bacteria in each sampling month the lowest level was found in stage 1. Airborne bacteria in the size range of 2.1-4.7 $\mu \mathrm{m}$ accounted for more than $56 \%$ of the total amount in June and September.

For airborne fungi, the particle size distributions were similar in the four sampling seasons (Fig. 6). Most airborne fungi (55-76 \%) were in the size range of $1.1-3.3 \mu \mathrm{m}$. There airborne fungi of particle sizes larger than $7 \mu \mathrm{m}$ comprised 12,10 , and $15 \%$ of the total amount in March, June, and September, respectively.

The risks associated with exposure to aerosols are not only related to concentration, but also to the size of aerosolized particles. The microbial particles with different diameter sizes present various effects on human health and the environment. Small particles can enter the lungs easier and deeper than large particles. Large particles $(>10 \mu \mathrm{m})$ are deposited in the upper respiratory tract (nose and nasopharynx), whereas particles with a diameter of $1-5 \mu \mathrm{m}$ caused the most serious injury because they are easily transported into the lungs; particles with diameters in the range 1-2 $\mu \mathrm{m}$ have the greatest retention in the alveoli (Bauer et al. 2002). Small bioaerosol particles $(<1 \mu \mathrm{m})$ can penetrate into the deepest parts of the respiratory tract (Horner et al. 1995). Liu and Ma (2010) pointed out that microbial particles in the size range of 2.1-4.7 $\mu \mathrm{m}$ can easily enter the trachea and bronchus, and microbial particles in the size range of $0.65-2.1 \mu \mathrm{m}$ can freely enter the alveoli, thereby easily causing respiratory infection in the human body. In the present study, $62 \%$ of the bacteria were within

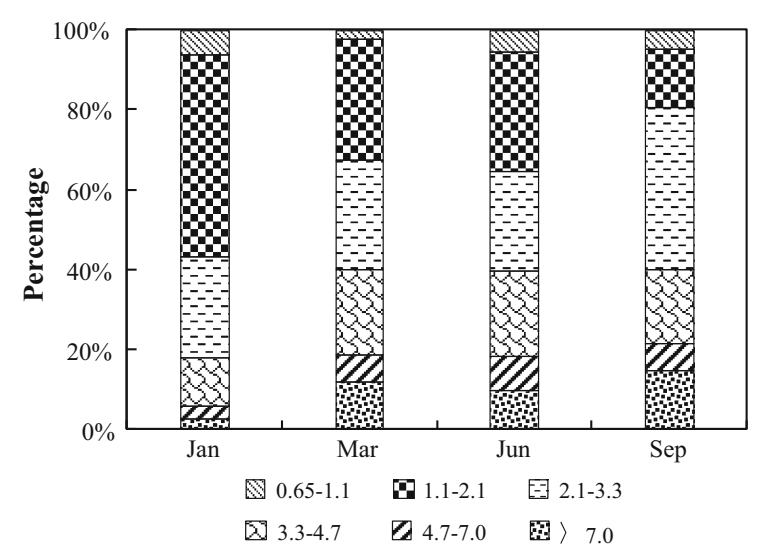

Fig. 6 Particle size distributions of airborne fungi in each sampling month 
the size range of 2.1-4.7 $\mu \mathrm{m}$, and the majority of fungi (55-76\%) were in the size range of $1.1-3.3 \mu \mathrm{m}$, which showed that the bacterial and fungal microbial aerosols present in the WWTS have certain health risks and may cause respiratory infection.

\subsubsection{Site-related variation in the particle size distribution of airborne bacteria and fungi}

Site-related particle size distribution of airborne bacteria and fungi are shown in Fig. 7. The proportion of airborne bacteria with particle sizes larger than $4.7 \mu \mathrm{m}$ was higher in S2 (38\%) than in S1 (20\%), whereas the proportion of airborne bacteria with particle sizes smaller than $2.1 \mu \mathrm{m}$ was lower in S2 (3\%) than in S1 $(24 \%)$. Particle size distribution characteristic of airborne fungi was unlike that of airborne bacteria. Ratio of airborne fungi with particle sizes in the range 1.1-3.3 $\mu \mathrm{m}$ in $\mathrm{S} 1$ (55\%) was lower than in S2 (36\%), and the ratio of airborne fungi with larger particle sizes (in the range 3.3-7.0 $\mu \mathrm{m}$ ) was higher in S2 $(50 \%)$ than in S1 $(30 \%)$. The particle size distribution of the bioaerosols could be varied depending on the sampling positions because the distances between sampling sites and the bioaerosol sources were different.

The bioaerosol particles settled because of gravity during their movement in the air, thereby leading to variation in particle size distribution from one sampling site to another. The particles with large sizes were prone to settling on the ground. S2 was located $0.5 \mathrm{~m}$ high from the ground, and $\mathrm{S} 1$ was set at $2 \mathrm{~m}$

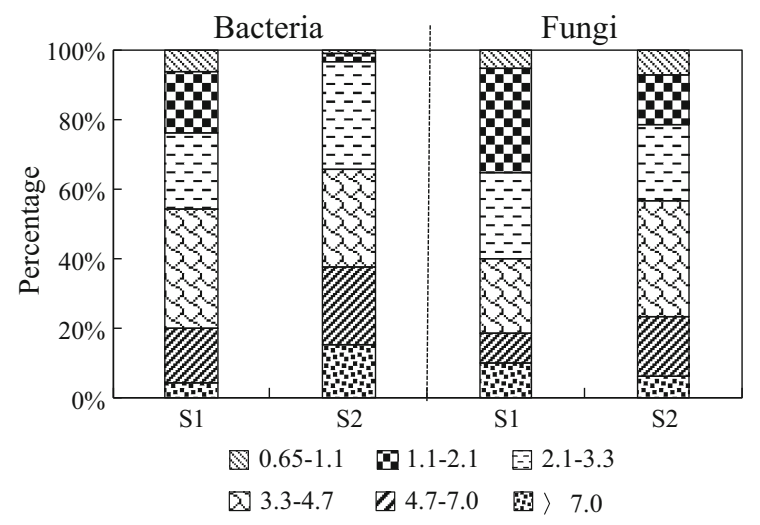

Fig. 7 Site-related particle size distribution of airborne bacteria and fungi above the ground; thus, $\mathrm{S} 1$ was much higher than that of S2. Therefore, most of the bioaerosol particles detected in S2 had particle sizes of $>3.3 \mu \mathrm{m}$ because of settling and accumulation of large particles.

\subsection{Microbial structure of airborne bacteria}

\subsubsection{Clone libraries coverage and phylogenetic analysis}

Samples collected in January (Jan-S1), June (Jun-S1 and Jun-S2), and September (Sep-S1) were analyzed to determine the microbial structure. Samples from March were excluded. The diversity of the 16S rDNAbased phylotypes was determined by analyzing clones from each of the clone libraries. A total of 198 clones were compared. Seven different OTUs existed among the 50 screened clones from Jan-S1, whereas 15 OTUs of 49 screened clones from Jun-S1, 14 OTUs of 49 screened clones from Jun-S2, and 7 OTUs of 50 screened clones from Sep-S1 were identified.

Coverage analysis indicated that the bioaerosol libraries represented approximately 82-94\% of the total number of clones examined, thereby providing a dependable inventory of the bacterial 16S rRNA gene sequences present in the bioaerosols. The $C$ values observed in all the samples were larger than 0.82 , thereby indicating that the clone number analyzed in each sample in the present study is accepted as valid in microbial diversity analysis. Sequences were assigned to a bacterial phylum according to their position in the phylogenetic tree (Figs. 8, 9, 10). The trees were based on consensus sequences resulting from a contiguous assembly based on $\geq 97 \%$ similarity. The diversities of bacterial species were 1.15 for January, 1.35 for June, and 0.83 for September. Samples collected in June presented the highest species richness among the three clone libraries.

\subsubsection{Genetic structure of airborne bacterial communities}

The majority of sequences in January were Virgibacillus dokdonensis (40\%), Bacillus sp. (34\%), and Lysinibacillus (24\%). L. sphaericus and L. fusiformis were identified among the Lysinibacillus species collected in the samples. The leading sequences in Jun-S1 were Acinetobacter sp. (40.82\%) and Bacillus sp. (38.78\%) with B. aerophilus, B. subtilis, and B. 


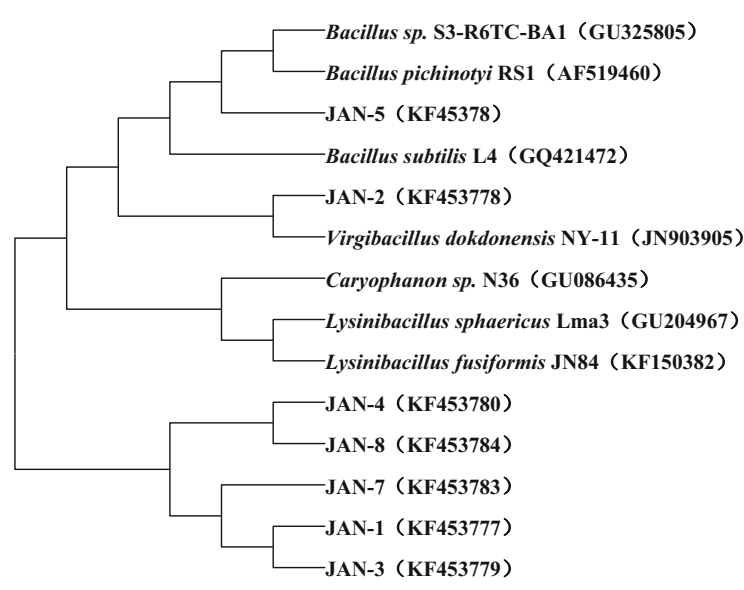

Fig. 8 Phylogenetic tree based on partial 16S rRNA gene sequences from sample collected in January and reference sequences in GenBank

licheniformis. The minor sequences included $S$. saprophyticus subsp. saprophyticus, Paenibacillus assamensis, L. sphaericus, and Enterobacter with E. cloacae, E. mori, and E. hormaechei. The dominant of sequences in September were assigned to Bacillus sp. $(50.0 \%)$ and L. sphaericus $(46.0 \%)$. P. globulus (4\%) was also detected in samples collected in September.

The identified bacteria of the $16 \mathrm{~S}$ rDNA clone libraries from all three sampling months belonged to the genera Bacillus and Lysinibacillus. Bacillus sp. and Lysinibacillus sp. could be frequently detected in WWTP, wastewater, and bioaerosols (Wan et al. 2010; Zulkifly et al. 2010). Bacillus sp. could tolerate the poor ventilation conditions. Under harsh environmental conditions, the cells of Bacillus produce oval endospores that remain dormant for extended periods and can invade epithelial cells and cause pulmonary infection. Bacillus sp. is widely found in WWTPs (Shokrollahzadeh et al. 2008). B. licheniformis is a Gram-positive, spore-forming soil bacterium, which produces an assortment of extra cellular enzymes that may contribute to nutrient cycling in nature (Remoroza et al. 2015). $L$. sphaericus is a Gram-positive, mesophilic, and rod-shaped bacterium. Under harsh conditions, $L$. sphaericus can form dormant endospores that are resistant to heat, chemicals, and ultraviolet light (Go et al. 2014).
V. dokdonensis (40\%) and Caryophanon (2\%) were also identified from the samples collected in January. More species of bacteria were found in the samples collected in June, including A. lwoffii and Acinetobacter sp. (40.82 \%), Staphylococcus saprophyticus subsp. saprophyticus (2.04\%), P. assamensis (2.04\%), and Enterobacter sp. (6.12\%). Except for Bacillus and Lysinibacillus, only Paucisalibacillus globulus (4 \%) existed in September.

A. lwoffii may play an important role in preventing allergy and asthma, and especially in the protection of prenatal cases (Conrad et al. 2009). S. saprophyticus is a uropathogenic bacteria frequently isolated from young female outpatients presenting with uncomplicated urinary tract infections (Kuroda et al. 2005). Enterobacter sp. was an important pathogenic bacterium that causes infectious diseases including skin soft tissue infection, respiratory infection, urinary tract infection, and sepsis because of the widespread use of antibiotics (Brodka et al. 2012; Korzeniewska and Harnisz 2012). Future studies should focus more on the potential health risk of exposure to Acinetobacter, $S$. saprophyticus, and Enterobacter sp.

\subsubsection{Seasonal variation and site-related distribution of airborne bacteria}

The distribution and diversity of bacteria in the bioaerosols were uneven and demonstrated site-related and seasonal variation. More species were found in June than in January and September (Fig. 11), thereby indicating that a great number of bacteria can live in the summer because of the ideal temperature and relative humidity during this season. All bacteria collected in January and September belonged to Firmicutes, as identified via DNA sequence analysis. The bacterial species collected in June were members of Proteobacteria and Firmicutes.

$\mathrm{S} 2$ was situated $6.5 \mathrm{~m}$ from the rotating brushes, and $\mathrm{S} 1$ was situated $0.5 \mathrm{~m}$ above the ground. The distance between $\mathrm{S} 1$ and $\mathrm{S} 2$ was $5 \mathrm{~m}$. Results of microbial species analysis showed that Enterobacter was the dominant group, whereas Klebsiella, Pantoea, and Citrobacter appeared as minor groups in S2 in June (Figs. 12, 13). The proportion of Enterobacter increased obviously from $6.12 \%$ in S1 to $80 \%$ in S2. Acinetobacter and Bacillus, which originally emerged in S1, could not be found in S2. Klebsiella, Pantoea, 
Fig. 9 Phylogenetic tree showing the relationship of representative sequences in June and reference sequences in GenBank

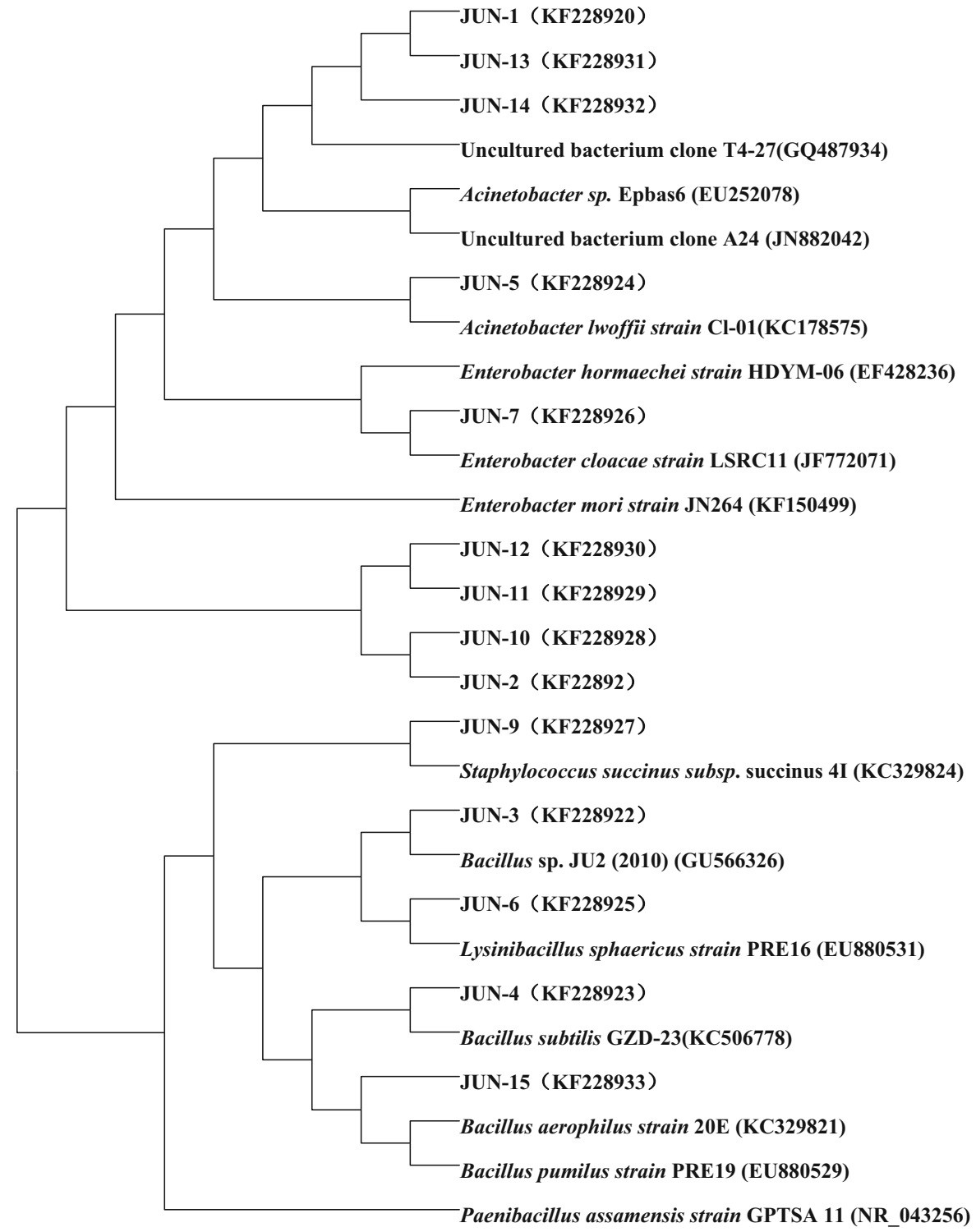

and Citrobacter appeared as new groups in S2. Results of particle size distribution showed that the amount of small particles decreased and that of large particles increased from S1 to S2. Enterobacter probably adhered to the large particles and was detected in S2. Enterobacter is a microorganism that is dangerous to the human health. Thus, effective methods must be implemented to reduce the infection risk caused by Enterobacter. Acinetobacter and Bacillus might attach to small-sized particles, which are suspended easily in the air.

\section{Conclusions}

The amounts of airborne bacteria detected in the WWTS were $1458 \pm 434 \mathrm{CFU} / \mathrm{m}^{3}$ in January, $1597 \pm 24 \mathrm{CFU} / \mathrm{m}^{3}$ in March, $4155 \pm 550 \mathrm{CFU} / \mathrm{m}^{3}$ in June, and $2491 \pm 149 \mathrm{CFU} / \mathrm{m}^{3}$ in September, respectively. The highest level of airborne fungi was obtained in June $\left(883 \pm 150 \mathrm{CFU} / \mathrm{m}^{3}\right)$, and the lowest level was obtained in March $\left(169 \pm 40 \mathrm{CFU} / \mathrm{m}^{3}\right)$. The levels of airborne bacteria and fungi presented seasonal and site-related variations. The highest 
Fig. 10 Phylogenetic tree showing the relationship of representative sequences in September and reference sequences in GenBank

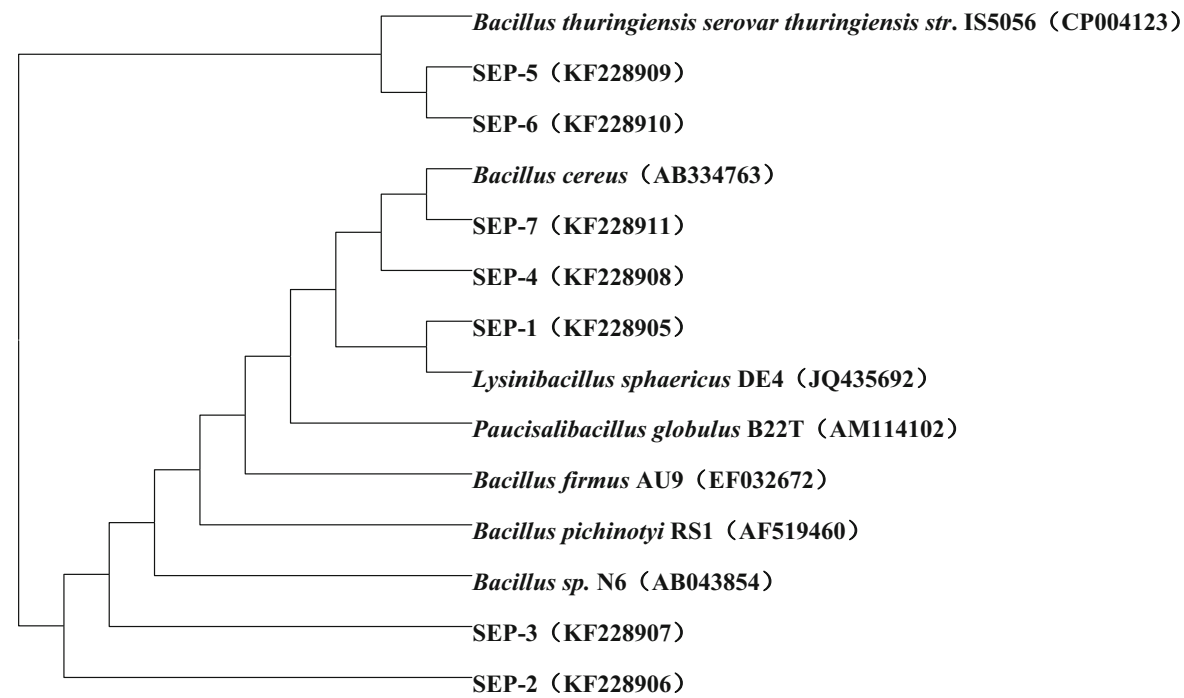

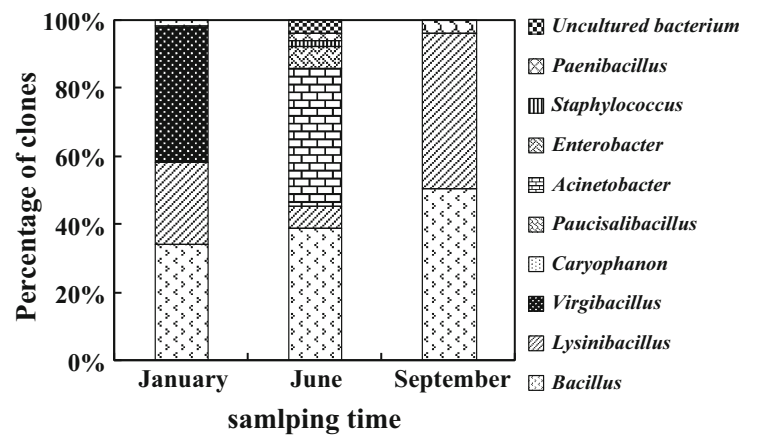

Fig. 11 Relative phylotype frequencies of clones isolated from examined samples

concentrations of airborne bacteria and fungi were obtained during summer and near rotating brushes. The particle size of the bioaerosols varied according to sampling positions and seasons. Most bacteria and fungi were detected on particles in the size range of 1.1-4.7 $\mu \mathrm{m}$. Large-sized particles tended to settle on the ground, whereas small-sized particles could easily float in the air.

In sampling site $\mathrm{S} 1$, Bacillus sp. comprised the majority of sequences in January, June, and September. L. sphaericus showed the same dominance in terms of number of sequences in January and September. Enterobacter was the leading group in S2, whereas Acinetobacter and Bacillus, which were originally obtained in S1, could not be found in $\mathrm{S} 2$ in June.

In the study of bioaerosols emitted from the WWTS, the concentration of bioaerosols, the particle size distribution, and microbial species need to be considered. Effective methods to protect the workers of WWTS from the harm of airborne bacteria and fungi emitted from the indoor WWTS are necessary, especially in summer when the meteorological parameters were suitable for the growth of bacteria. Convection of the air could be increased, and the concentration of bioaerosols could be diluted by adding ventilation to the WWTS. Previous research showed that the level of bacteria in the WWTS air reached the National Indoor Air Quality Standard of China after $2 \mathrm{~h}$ of ventilation, and $66.33 \%$ of airborne bacteria and $62.95 \%$ of fungi were reduced within $4 \mathrm{~h}$ of air exchange at a flow rate $50 \mathrm{~m}^{3} / \mathrm{min}$ (Guo et al. 2014). Ultraviolet rays can inactivate the bioaerosols. To reduce the infection risk to the workers in the WWTS, ventilating the room and installing a UV lamp are two effective methods that can be used to control the bioaerosols emitted from the WWTS. Starting ventilation and turning on the UV lamp before the arrival of workers to the WWTS might provide a relatively safe environment to protect the health of workers. Meanwhile, the emission of bioaerosols to the surroundings could also be reduced. 
Fig. 12 Phylogenetic tree showing the relationship of representative sequences in $\mathrm{S} 2$ in June and reference sequences in GenBank

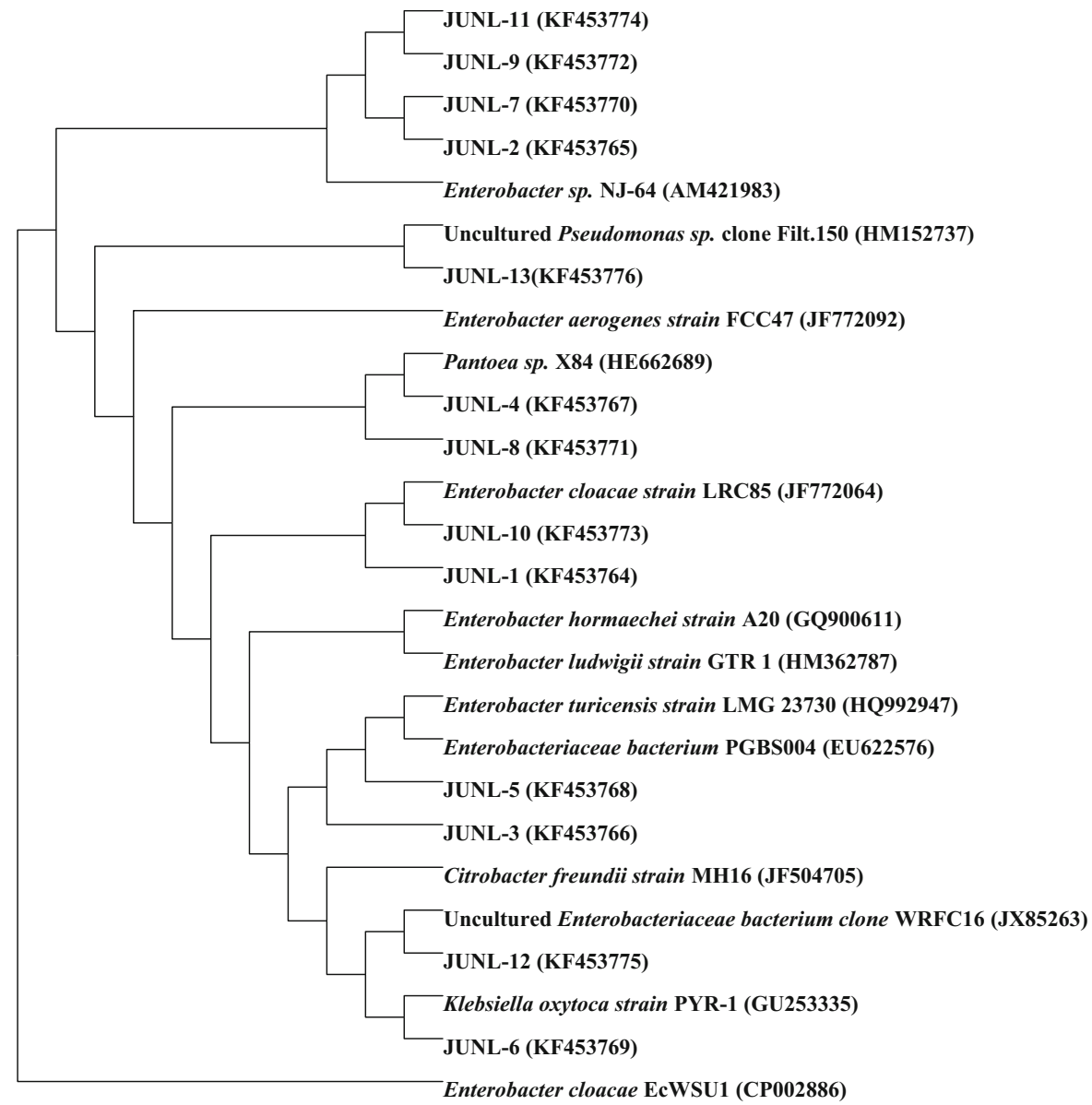

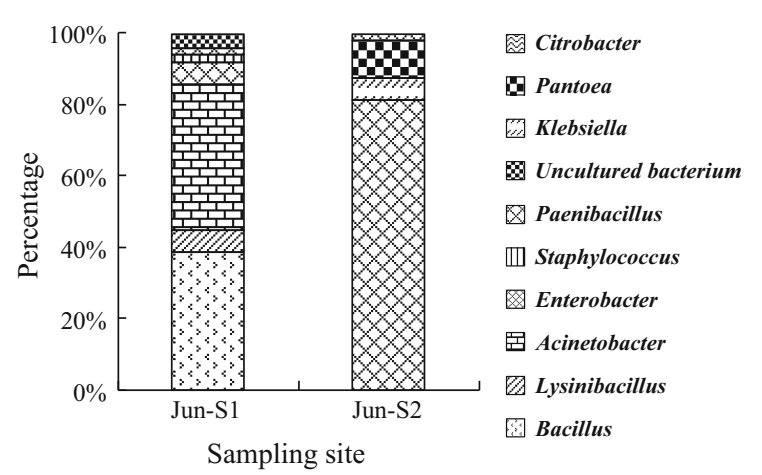

Fig. 13 Species of airborne bacteria in S1 and S2 in June

Acknowledgments The authors express their sincere acknowledgements to Dr. John for the English revision of the manuscript. The work was financially supported by the Young Scientists Fund of Research Center for Eco-Environmental Sciences, Chinese Academy of Sciences (No. RCEES-QN20130006F), and the National Natural Science Foundation of China (No. 51478456).

\section{References}

Andersen, A. A. (1958). New sampler for the collection, sizing, and enumeration of viable airborne particles. Journal of Bacteriology, 76(5), 471-484.

Bauer, H., Fuerhacker, M., Zibuschka, F., Schmid, H., \& Puxbaum, H. (2002). Bacteria and fungi in aerosols generated by two different types of wastewater treatment plants. Water Research, 36(16), 3965-3970.

Brandi, G., Sisti, M., \& Amagliani, G. (2000). Evaluation of the environmental impact of microbial aerosols generated by wastewater treatment plants utilizing different aeration systems. Journal of Applied Microbiology, 88(5), 845-852.

Brodka, K., Kozajda, A., Buczynska, A., \& SzadkowskaStanczyk, I. (2012). The variability of bacterial aerosol in poultry houses depending on selected factors. International Journal of Occupational Medicine and Environmental Health, 25(3), 281-293.

Conrad, M. L., Ferstl, R., Teich, R., Brand, S., Blumer, N., Yildirim, A. O., et al. (2009). Maternal TLR signaling is required for prenatal asthma protection by the nonpathogenic microbe Acinetobacter lwoffii F78. Journal of Experimental Medicine, 206(13), 2869-2877. 
De Luca, G., Zanetti, F., Perari, A. C., \& Stampi, S. (2001). Airborne coagulase negative staphylococci produced by a sewage treatment plant. International Journal of Hygiene and Environmental Health, 204(4), 231-238.

Ding, Y., Wu, W. X., Han, Z. Y., \& Chen, Y. X. (2008). Correlation of reactor performance and bacterial community composition during the removal of trimethylamine in three-stage biofilters. Biochemical Engineering Journal, 38(2), 248-258.

Douwes, J., Thorne, P., Pearce, N., \& Heederik, D. (2003). Bioaerosol health effects and exposure assessment: Progress and prospects. Annals of Occupational Hygiene, 47(3), 187-200.

Fahlgren, C., Bratbak, G., Sandaa, R. A., Thyrhaug, R., \& Zweifel, U. L. (2011). Diversity of airborne bacteria in samples collected using different devices for aerosol collection. Aerobiologia, 27(2), 107-120.

Filipkowska, Z. (2003). Sanitary and bacteriological aspects of sewage treatment. Acta Microbiologica Polonica, 52, 57-66.

Filipkowska, Z., Janczukowicz, W., Krzemieniewski, M., \& Pesta, J. (2000). Microbiological air pollution in the surroundings of the wastewater treatment plant with activatedsludge tanks aerated by horizontal rotors. Polish Journal of Environmental Studies, 9(4), 273-280.

Fracchia, L., Pietronave, S., Rinaldia, M., \& Martinotti, M. G. (2006). Site-related airborne biological hazard and seasonal variations in two wastewater treatment plants. Water Research, 40(10), 1985-1994.

Gangamma, S., Patil, R. S., \& Mukherji, S. (2011). Characterization and proinflammatory response of airborne biological particles from wastewater treatment plants. Environmental Science and Technology, 45(8), 3282-3287.

GB/T18883-2002. (2002). Standards for indoor air quality. Beijing: Standards press of China.

Go, J., Lee, K. M., Park, Y., \& Yoon, S. S. (2014). Extended longevity and robust early-stage development of Caenorhabditis elegans by a soil microbe, Lysinibacillus sphaericus. Environmental Microbiology Reports, 6(6), 730-737.

Good, I. J. (1953). The population frequencies of species and the estimation of population parameters. Biometrika, 40, 237-264.

Guo, X. S., Wu, P. P., Ding, W. J., Zhang, W. Y., \& Li, L. (2014). Reduction and characterization of bioaerosols in a wastewater treatment station via ventilation. Journal of Environmental Sciences-China, 26(8), 1575-1583.

Haas, D., Unteregger, M., Habib, J., Galler, H., Marth, E., \& Reinthaler, F. F. (2010). Exposure to bioaerosol from sewage systems. Water, Air, and Soil pollution, 207(1-4), 49-56.

Han, Y. P., Li, L., Liu, J. X., \& Zhang, M. Z. (2012). Microbial structure and chemical components of aerosols caused by rotating brushes in a wastewater treatment plant. Environmental Science and Pollution Research, 19(9), 4097-4108.

Handley, B. A., \& Webster, A. J. F. (1995). Some factors affecting the airborne survival of bacteria outdoors. Journal of Applied Bacteriology, 79(4), 368-378.

Heinonen-Tanski, H., Reponen, T., \& Koivunen, J. (2009). Airborne enteric coliphages and bacteria in sewage treatment plants. Water Research, 43(9), 2558-2566.

Horner, W. E., Helbling, A., Salvaggio, J. E., \& Lehrer, S. B. (1995). Fungal allergens. Clinical Microbiology Reviews, $8(2), 161-179$.
Huang, C. Y., Lee, C. C., Li, F. C., Ma, Y. P., \& Su, H. J. J. (2002). The seasonal distribution of bioaerosols in municipal landfill sites: A 3-yr study. Atmospheric Environment, 36(27), 4385-4395.

Jones, A. M., \& Harrison, R. M. (2004). The effects of meteorological factors on atmospheric bioaerosol concentrations-A review. Science of the Total Environment, 326(1-3), 151-180.

Kay, D., Crowther, J., Stapleton, C. M., Wyer, M. D., Fewtrell, L., Edwards, A., et al. (2008). Faecal indicator organism concentrations in sewage and treated effluents. Water Research, 42(1-2), 442-454.

Korzeniewska, E., Filipkowska, Z., Gotkowska-Plachta, A., Janczukowicz, W., Dixon, B., \& Czulowska, M. (2009). Determination of emitted airborne microorganisms from a BIO-PAK wastewater treatment plant. Water Research, 43(11), 2841-2851.

Korzeniewska, E., \& Harnisz, M. (2012). Culture-dependent and culture-independent methods in evaluation of emission of enterobacteriaceae from sewage to the air and surface water. Water, Air, and Soil pollution, 223(7), 4039-4046.

Kuroda, M., Yamashita, A., Hirakawa, H., Kumano, M., Morikawa, K., Higashide, M., et al. (2005). Whole genome sequence of Staphylococcus saprophyticus reveals the pathogenesis of uncomplicated urinary tract infection. Proceedings of the National Academy of Sciences of the United States of America, 102(37), 13272-13277.

Li, L., Gao, M., \& Liu, J. X. (2011). Distribution characterization of microbial aerosols emitted from a wastewater treatment plant using the Orbal oxidation ditch process. Process Biochemistry, 46(4), 910-915.

Li, L., Han, Y. P., \& Liu, J. X. (2013). Assessing genetic structure, diversity of bacterial aerosol from aeration system in an oxidation ditch wastewater treatment plant by culture methods and bio-molecular tools. Environmental Monitoring and Assessment, 185(1), 603-613.

Liu, J. W., \& Ma, W. L. (2010). Characteristics of microbial aerosol pollution in pig house. Animal Husbandry and Feed Science, 2, 41-44.

Macher, J. M. (1989). Positive-hole correction of multiple-jet impactors for collecting viable microorganisms. American Industrial Hygiene Association Journal, 50(11), 561-568.

Malakootian, M., Radhakrishna, N., Mazandarany, M. P., \& Hossaini, H. (2013). Bacterial-aerosol emission from wastewater treatment plant. Desalination and Water Treatment, 51(22-24), 4478-4488.

Maron, P. A., Lejon, D. P. H., Carvalho, E., Bizet, K., Lemanceau, P., Ranjard, L., \& Mougel, C. (2005). Assessing genetic structure and diversity of airborne bacterial communities by DNA fingerprinting and $16 \mathrm{~S}$ rDNA clone library. Atmospheric Environment, 39(20), 3687-3695.

Marthi, B., Fieland, V. P., Walter, M., \& Seidler, R. J. (1990). Survival of bacteria during aerosolization. Applied and Environmental Microbiology, 56(11), 3463-3467.

O'Gorman, C. M., \& Fuller, H. T. (2008). Prevalence of culturable airborne spores of selected allergenic and pathogenic fungi in outdoor air. Atmospheric Environment, 42(18), 4355-4368.

Peccia, J., Werth, H. M., Miller, S., \& Hernandez, M. (2001). Effects of relative humidity on the ultraviolet induced 
inactivation of airborne bacteria. Aerosol Science and Technology, 35(3), 728-740.

Pillai, S. D., \& Ricke, S. C. (2002). Bioaerosols from municipal and animal wastes: Background and contemporary issues. Canadian Journal of Microbiology, 48(8), 681-696.

Polymenakou, P. N., Mandalakis, M., Stephanou, E. G., \& Tselepides, A. (2008). Particle size distribution of airborne microorganisms and pathogens during an intense African dust event in the eastern Mediterranean. Environmental Health Perspectives, 116(3), 292-296.

Remoroza, C., Wagenknecht, M., Buchholt, H. C., Moerschbacher, B. M., Gruppen, H., \& Schols, H. A. (2015). Mode of action of Bacillus licheniformis pectin methylesterase on highly methylesterified and acetylated pectins. Carbohydrate Polymers, 115, 540-550.

Sanchez-Monedero, M. A., Aguilar, M. I., Fenoll, R., \& Roig, A. (2008). Effect of the aeration system on the levels of airborne microorganisms generated at wastewater treatment plants. Water Research, 42(14), 3739-3744.

Shokrollahzadeh, S., Azizmohseni, F., Golmohammad, F., Shokouhi, H., \& Khademhaghighat, F. (2008).
Biodegradation potential and bacterial diversity of a petrochemical wastewater treatment plant in Iran. Bioresource technology, 99(14), 6127-6133.

Tsai, M. Y., \& Liu, H. M. (2009). Exposure to culturable airborne bioaerosols during noodle manufacturing in central Taiwan. Science of the Total Environment, 407(5), 1536-1546.

Wan, S. G., Li, G. Y., An, T. C., Guo, B., Sun, L., Zu, L., \& Ren, A. L. (2010). Biodegradation of ethanethiol in aqueous medium by a new Lysinibacillus sphaericus strain RG-1 isolated from activated sludge. Biodegradation, 21(6), 1057-1066.

Xia, S. B., \& Liu, J. X. (2004). An innovative integrated oxidation ditch with vertical circle for domestic wastewater treatment. Process Biochemistry, 39(9), 1111-1117.

Zulkifly, A. H., Roslan, D. D., Hamid, A. A. A., Hamdan, S., \& Huyop, F. (2010). Biodegradation of low concentration of monochloroacetic acid-degrading Bacillus sp. TW1 isolated from terengganu water treatment and distribution plant. Journal of Applied Sciences, 10(22), 2940-2944. 